Archive for

Organic Chemistry
Arkivoc 2018, part vii, 0-0

to be inserted by editorial office

\title{
Synthesis of 2-heterosubstituted cyclopent-2-en-1-ones: a preliminary study of the strategic design of antiviral compounds
}

\author{
Karzan Khaleel Hameed, ${ }^{a}$ Ahmed Anwar Dezaye, ${ }^{a *}$ Faiq Hamasaid Hussain, ${ }^{b}$ \\ Teresa Basile, ${ }^{\mathrm{c}}$ Misal Giuseppe Memeo, ${ }^{\mathrm{c}}$ and Paolo Quadrellic ${ }^{*}$ \\ ${ }^{a}$ Salahaddin University - Erbil, Department of Chemistry, College of Science, Erbil, Iraq \\ ${ }^{b}$ Research Center-Ishik University, Erbil, Kurdistan Region-(Iraq). \\ 'University of Pavia, Department of Chemistry, Viale Taramelli 12, 27100 - Pavia, Italy \\ Email:paolo.quadrelli@unipv.it
}

\section{Abstract}

A synthetic approach to heterosubstituted cyclopent-2-en-1-ones through a robust protocol that leads to single 2-substituted compounds is reported. In view of a strategic design of antiviral compounds, the methodology was applied to substituted benzoimidazoles as neutral heterocyclic systems, as models for preliminary evaluation of their antiviral activities. By virtue of NMR investigations the synthetized compounds were structurally completely defined and the conformations were also located from DFT calculations. The preliminary biological tests revealed a general inactivity for most of the products with significant predictions for some bearing specific substituents. The results suggested possible structural changes apt to trigger the relative biological activities, to implement them in the new compounds.
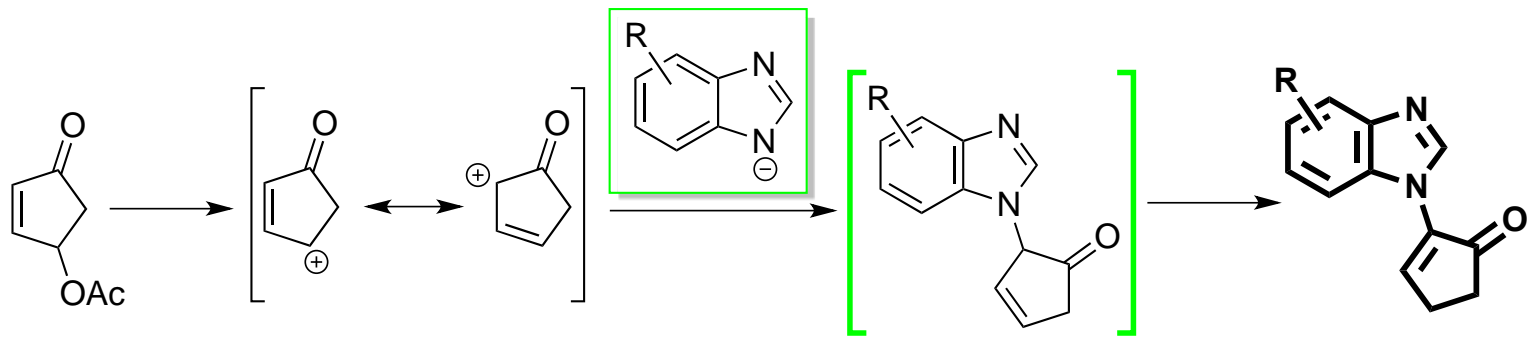

Keywords: Cyclopent-2-en-1-one, Antivirals, Heterobases, Benzoimidazoles, Nucleophilic substitution 


\section{Introduction}

Racemic and enantiomerically pure 4-oxocyclopent-2-en-1-yl acetates 1 are valuable intermediates in organic synthesis, often employed in the short-cut preparation of nucleoside analogues with pyrimidine and purine heterobases. ${ }^{1}$ The chemistry of these scaffolds have been extensively investigated and reviewed since the hydroxycyclopentenone moiety often appear in natural and bioactive products ${ }^{2}$ or constitutes the privileged starting compound for their synthesis. ${ }^{3}$ Carreira and Ruider used the racemic acetate 1 for the total synthesis of Hyppolachnin A. ${ }^{4}$ Recently, Reiser and co-workers have got back the chemistry of the 4-hydroxy-2cyclopentenone for the enantioselective synthesis of ent-Norarisateromycin ${ }^{5}$ and other enantiopure guaianes and pseudoguaianolides. ${ }^{6}$ Moreover, they have also applied this scaffold for the total synthesis of Sibirinone and other pyranone derivatives. ${ }^{7}$ In a previous work, we investigated the use of acetate $\mathbf{1}$ as a substrate for the functionalization with uracil, thymine, 6-chloropurine and some adenines in a fast-track to nucleoside analogues. We found that the expected 4-heterosubstituted products could be obtained along with the isomeric 2-heterosubstituted compounds as minor components. Samples of selected products were evaluated for their antiviral activity in a primary screening against a variety of viruses belonging to different classes. One of them, belonging to the family of the 4-substituted cyclopentenones of type $\mathbf{2}$, was found to be highly active against HPV. Others, belonging to the family of the 2-substituted cyclopentenones of type 3, were found to be moderately active against Punta Toro virus and Rift Valley fever virus (Scheme 1). The protocol for their synthesis stands on a simple nucleophilic substitution of the acetate group of the cyclopentenone scaffold $\mathbf{1}$ with the desired heterobase. ${ }^{8}$

$( \pm)-1$

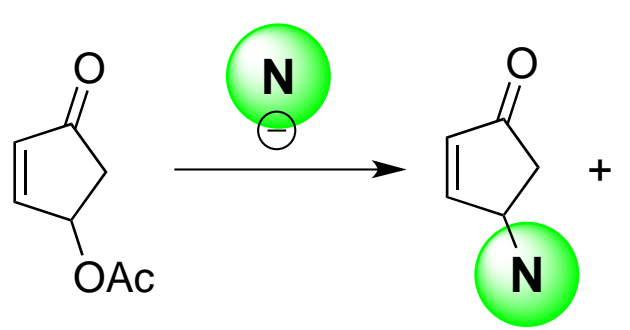

$( \pm)-2$

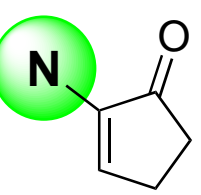

$( \pm)-3$

Scheme 1. Synthesis of 4-substituted- and 2-substituted-cyclopentenone derivatives.

On pursuing the investigations on the synthesis of nucleoside analogues based on the cyclopentenone scaffold, two elements were the focus of our subsequent researches. The first one regards the selectivity of the substitution process; upon adding the 4-oxocyclopent-2-en-1-yl acetate 1 at $0{ }^{\circ} \mathrm{C}$ to solutions of the heterobase anions in anhydrous acetonitrile and leaving under stirring for 3 hours, mixtures of the two regioisomeric products $\mathbf{2}$ and $\mathbf{3}$ were obtained. We have demonstrated that these compounds have different biological activity as antivirals. Now, our aim is to obtain single regioisomers, introducing a modified protocol apt to govern the selectivity outcome. In particular, our focus is to obtain the 2-substituted cyclopentenone derivatives that have previously displayed only modest antiviral activities in order to improve their performances by specific structural changes. Second, previously we have investigated purine and pyrimidine heterobases but, in theory, other heterocyclic compounds could be of remarkable interest for their potential biological activities, properly tuned by introducing of different substituents and/or heteroatoms and properly selected from the wide family of heterocyclic compounds. 
Here, we propose our design strategy by using benzoimidazoles derivatives bearing a variety of substituents that represent simple heterocyclic models, reactive enough as nucleophiles and suitable for locating structural changes or derivatization pathways. So, the aim is to develop a step-by-step tuning of a heterocycle structure, on the one hand, and, of the cyclopentenone moiety structure, on the other hand, in order to get the required information on the structure-activity relationship (SAR) for these types of molecules, with the help of suitable and corroborating biological evaluations.

\section{Results and Discussion}

The racemic 4-oxocyclopent-2-en-1-yl acetate ${ }^{9}(\mathbf{t})-\mathbf{1}$ was obtained by acetylation reaction ${ }^{10}$ of the corresponding 4-hydroxy-2-cyclopentenone according to known procedures. ${ }^{5,11}$

The coupling reactions were conducted by in situ generation of the conjugated bases of the commercially available substituted benzoimidazole heterocycles $\mathbf{4 a - d}$ with $\mathrm{NaH} 95 \%$ in dry acetonitrile (Scheme 2). The benzoimidazole anions generation required the use of a Schlenk tube apparatus under vacuum, stirring the suspension for 15 minutes at room temperature. Afterwards, the acetonitrile solution of the cyclopentenone acetate 1 was added and the reactions were left under stirring in inert atmosphere overnight at room temperature. Quenching was performed by pouring the mixtures in ice mixed with $\mathrm{NaCl} / \mathrm{NH}_{4} \mathrm{Cl} 1: 3$. Extraction with DCM allowed for the obtaining of organic phases that were dried over anhydrous $\mathrm{Na}_{2} \mathrm{SO}_{4}$. Residues were submitted to chromatographic separation to isolate the products and purification (Scheme 2).

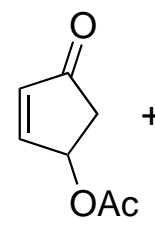

$( \pm)-1$<smiles>[R]c1ccc2[nH]cnc2c1</smiles>

4a-d

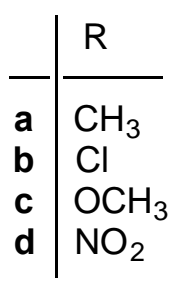

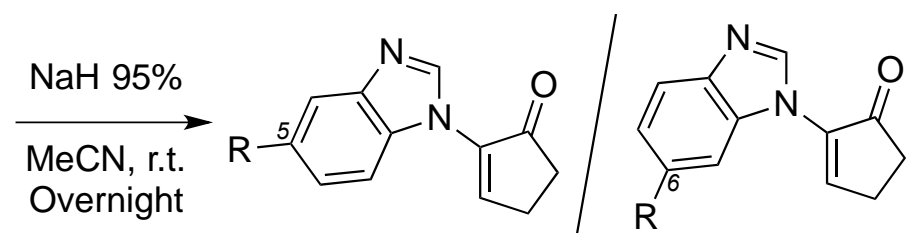

5a-d

6a-d

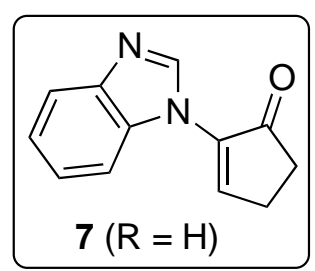

Scheme 2. Synthesis of 2-benzoimidazole-cyclopentenone derivatives $\mathbf{5}$ and $\mathbf{6}$.

In order to get evidence of possible electronic effects on the reaction outcome, the selected benzoimidazoles $\mathbf{4 a - d}$, which contain substituents with different electron-donor or electron-withdrawing capacities. Compound $\mathbf{7}$ containing the substituent-free benzoimidazole ring was also synthesized for comparison purposes. From the reaction mixtures 2-substituted cyclopentenones derivatives were obtained selectively, as mixtures of compounds $\mathbf{5 a - d}$ and $\mathbf{6 a - d}$, derived from different orientation in the coupling reaction of the benzoimidazole rings, not separable by any chromatographic technique at this step of the designed protocol. Compounds 5a-d are obtained in fact from the addition of the benzoimidazole at the N1 nitrogen atom while compounds $6 \mathbf{a - d}$ at the N3 nitrogen atom, since they exist in two equilibrium forms when react with $\mathrm{NaH}$. No 4-substituted cyclopentenone derivatives (type $\mathbf{2}$ of Scheme 1) were isolated or even detected in the crude reaction mixtures. The synthetic method leads selectively to the 2-substituted 

compounds (type $\mathbf{3}$ of Scheme 1). Compounds $\mathbf{5 a - d}$ and $\mathbf{6 a - d}$ were obtained as inseparable mixtures of regioisomers, as every attempt to separated them with chromatographic techniques failed due to the low level of structural differentiation between the single pairs. Table 1 reports chemical yields, physical data and the relevant IR bands of the synthetized adducts. The yields are good in all the cases. They never reach quantitative values due to partial decomposition of the starting acetate compound 1. It is known, in fact, that it is unstable upon standing at room temperature: decomposition starts in a couple of days to afford another unstable compound, the cyclopentadienenone (for mechanism, vide infra). From the structural point of view, the IR spectra clearly report the presence of the carbonyl $\mathrm{C}=\mathrm{O}$ groups and the $\mathrm{C}=\mathrm{N}$ bands referred to the imidazole moieties and the values are found at the expected wave numbers for these type of compounds.

Table 1. Chemical yields, physical data and relevant IR bands of compounds 5a-d, 6a-d and 7 (Scheme 2)

\begin{tabular}{llllll}
\hline Entry & $\mathbf{5 / 6}$ & $\begin{array}{l}\text { Yield } \\
(\%)\end{array}$ & $\begin{array}{l}\text { M.p. } \\
\left({ }^{\circ} \mathrm{C}\right)^{\mathrm{a}}\end{array}$ & $\begin{array}{l}\mathrm{IR}\left(\mathrm{cm}^{-1}\right)^{\mathrm{b}} \\
\mathrm{V}_{\mathrm{C}=\mathrm{O}}\end{array}$ & $\mathrm{V}_{\mathrm{C}=\mathrm{N}}$ \\
\hline 1 & a & 53 & $205-210$ & 1686 & 1607 \\
2 & $\mathbf{b}$ & 60 & $215-219$ & 1674 & 1595 \\
3 & $\mathbf{c}$ & 51 & 210 (dec.) & 1684 & 1607 \\
4 & $\mathbf{d}$ & 67 & $194-200$ & 1692 & 1590 \\
5 & $\mathbf{7}$ & 70 & $>250$ & 1678 & 1581 \\
\hline
\end{tabular}

aFrom diisopropyl ether with few drops of ethanol. ${ }^{b}$ Nujol mulls.

However, the structural assignment remained an open problem and was adequately solved even in the presence of mixtures of compounds by NMR experiments by collecting the ${ }^{1} \mathrm{H}$ NMR spectra in deuterated DMSO and analyzing the signals with the help of further experiments, such as COSY and NOESY and upon comparison with the single compound spectrum obtained from the reaction with benzoimidazole (adduct 7).

Table 2 reports the relevant signals as attributed according to the observation hereby exposed. All the spectra of the products and double resonance experiments spectra are given in the Supplementary Material (SM). Compounds 5a-d, bearing the substituent $\mathrm{R}$ on the $\mathrm{C5}$ of the benzoimidazole ring, are the minor components of the mixtures where the ratios range from 1:1.2 for compounds $\mathbf{5 / 6} \mathbf{6}, \mathbf{c}$ to $1: 2$ for the nitro

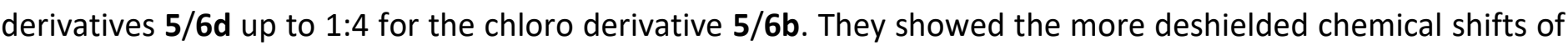
the $\mathrm{CH}=\mathrm{N}$ of the benzoimidazole ring with respect to the regioisomers $6 \mathbf{a}-\mathbf{d}$, while some order inversions are found for the signals corresponding to the olefinic $=\mathrm{CH}$ protons. The aromatic signals of the benzenic part of the heterocyclic moiety deserve the typical multiplicity relative to two protons with an ortho coupling, being one of them coupled with the third proton through a meta coupling constant (not always detectable). Protons $\mathrm{H}_{\mathrm{c}}$ in adducts 5a-c are more deshielded with respect to all the other signals presumably because of the proximity with the carbonyl group of the cyclopentenone moiety (free rotation around the $\mathrm{N}_{\text {HET }}-\mathrm{C}=$ bond) with a single exception of $\mathbf{5 d}$, where the nitro group displays deshielding effects on the other adjacent protons. The same happens for the protons $\mathrm{H}_{\mathrm{C}^{\prime}}$ of compounds $\mathbf{6 a , b , d}$ with the single exception of $\mathbf{5} \mathbf{c}$, where the methoxy group displays shielding effects on the other adjacent protons. The chemical shifts of the benzoimidazole 7 closely resemble those of the methyl derivatives and confirm that the $\mathrm{H}_{c}$ proton is the most deshielded among the aromatic protons because of the proximity with the carbonyl group of the cyclopentenone moiety. 
Table 2. ${ }^{1} \mathrm{H}$ NMR characterization of compounds 5 a-d, 6 a-d and 7 (Scheme 2)
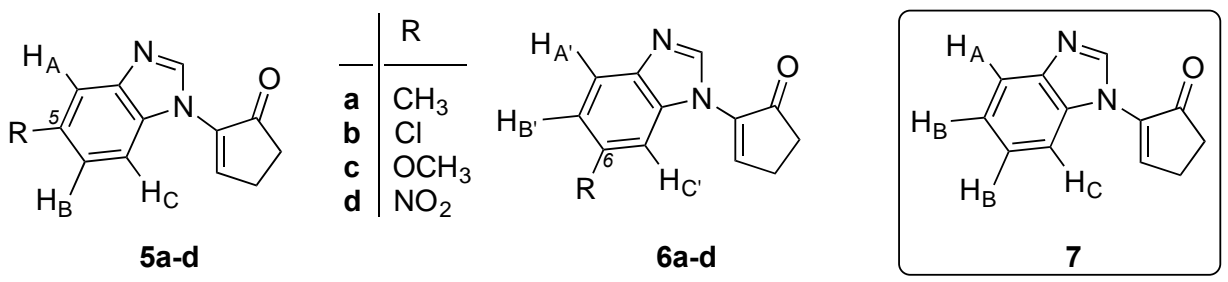

\begin{tabular}{lllllllllllllll}
\hline \multirow{2}{*}{ Entry } & $\mathbf{5}^{\mathrm{a}}$ & $\mathrm{NMR}$ & $\delta, \mathrm{CDCl}_{3}$ & \multicolumn{4}{c}{ Minor comp. } & $6^{\mathrm{a}}$ & $\mathrm{NMR}$ & \multicolumn{2}{c}{$\delta, \mathrm{CDCl}_{3}$} & \multicolumn{3}{c}{ Major comp. } \\
& & $\mathrm{CH}=\mathrm{N}$ & $\mathrm{H}_{\mathrm{x}}$ & $\mathrm{H}_{\mathrm{A}}$ & $\mathrm{H}_{\mathrm{B}}$ & $\mathrm{C}=\mathrm{CH}$ & $\mathrm{CH}=\mathrm{N}$ & $\mathrm{H}_{\mathrm{A}^{\prime}}$ & $\mathrm{H}_{\mathrm{C}^{\prime}}$ & $\mathrm{H}_{\mathrm{B}^{\prime}}$ & $\mathrm{C}=\mathrm{CH}$ \\
\hline 1 & $\mathbf{a}^{\mathrm{b}}$ & $8.72(\mathrm{~s})$ & $7.86(\mathrm{~d})$ & $7.60(\mathrm{~s})$ & $7.24(\mathrm{t})$ & $6.64(\mathrm{~s})$ & $\mathbf{a}^{\mathrm{b}}$ & $8.69(\mathrm{~s})$ & $7.66(\mathrm{~d})$ & $7.81(\mathrm{~s})$ & $7.24(\mathrm{t})$ & $6.67(\mathrm{~s})$ \\
2 & $\mathbf{b}^{\mathrm{c}}$ & $8.90(\mathrm{~s})$ & $8.06(\mathrm{~d})$ & $7.91(\mathrm{~d})$ & $7.45(\mathrm{~d})$ & $6.67(\mathrm{~s})$ & $\mathbf{b}^{\mathrm{c}}$ & $8.87(\mathrm{~s})$ & $7.82(\mathrm{~d})$ & $8.11(\mathrm{~d})$ & $7.45(\mathrm{~d})$ & $6.75(\mathrm{~s})$ \\
3 & $\mathbf{c}^{\mathrm{d}}$ & $8.76(\mathrm{~s})$ & $7.90(\mathrm{~d})$ & $7.36(\mathrm{~d})$ & $7.02(\mathrm{~d})$ & $6.59(\mathrm{~s})$ & $\mathbf{c}^{\mathrm{d}}$ & $8.67(\mathrm{~s})$ & $768(\mathrm{~d})$ & $7.34(\mathrm{~d})$ & $7.00(\mathrm{~d})$ & $6.67(\mathrm{~s})$ \\
4 & $\mathbf{d}^{\mathrm{d}}$ & $9.17(\mathrm{~s})$ & $8.02(\mathrm{~d})$ & $8.72(\mathrm{~d})$ & $8.27(\mathrm{~m})$ & $6.80(\mathrm{~s})$ & $\mathbf{d}^{\mathrm{e}}$ & $9.10(\mathrm{~s})$ & $8.27(\mathrm{~m})$ & $8.65(\mathrm{bs})$ & $8.27(\mathrm{~m})$ & $6.78(\mathrm{~s})$ \\
\hline 5 & $\mathbf{7}^{\mathrm{f}}$ & $8.83(\mathrm{~s})$ & $8.03(\mathrm{~m})$ & $7.81(\mathrm{~m})$ & $7.43(\mathrm{~m})$ & $6.65(\mathrm{~s})$ & & & & & & & & \\
\hline
\end{tabular}

aThe reaction was conducted in anoxic conditions. ${ }^{\mathrm{b}} \mathrm{At} 2.54$ and $3.37 \delta$ the $\mathrm{CH}_{2} \mathrm{CH}_{2}$ moiety is found for both $5 a$ and 6a. The Methyls are also found at 2.46 and $2.50 \delta$. ${ }^{\mathrm{C} A t} 2.55$ and $3.34 \delta$ the $\mathrm{CH}_{2} \mathrm{CH}_{2}$ moiety is found for both 5b and 6b. ${ }^{\mathrm{d}}$ Other signals; 5c, $\delta: 3.84$ (s, MeO). 6c, $\delta: 3.89$ (s, MeO). At 2.53 and $3.36 \delta$ the $\mathrm{CH}_{2} \mathrm{CH}_{2}$ moiety is found for both $\mathbf{5 c}$ and $6 \mathrm{c}$. ${ }^{\mathrm{e}} \mathrm{At} 2.58$ and $3.42 \delta$ the $\mathrm{CH}_{2} \mathrm{CH}_{2}$ moiety is found for both $\mathbf{5 d}$ and $\mathbf{6 d}$. ${ }^{\mathrm{f}} \mathrm{At} 2.55$ and 3.39 $\delta$ the $\mathrm{CH}_{2} \mathrm{CH}_{2}$ moiety is found for 7 .

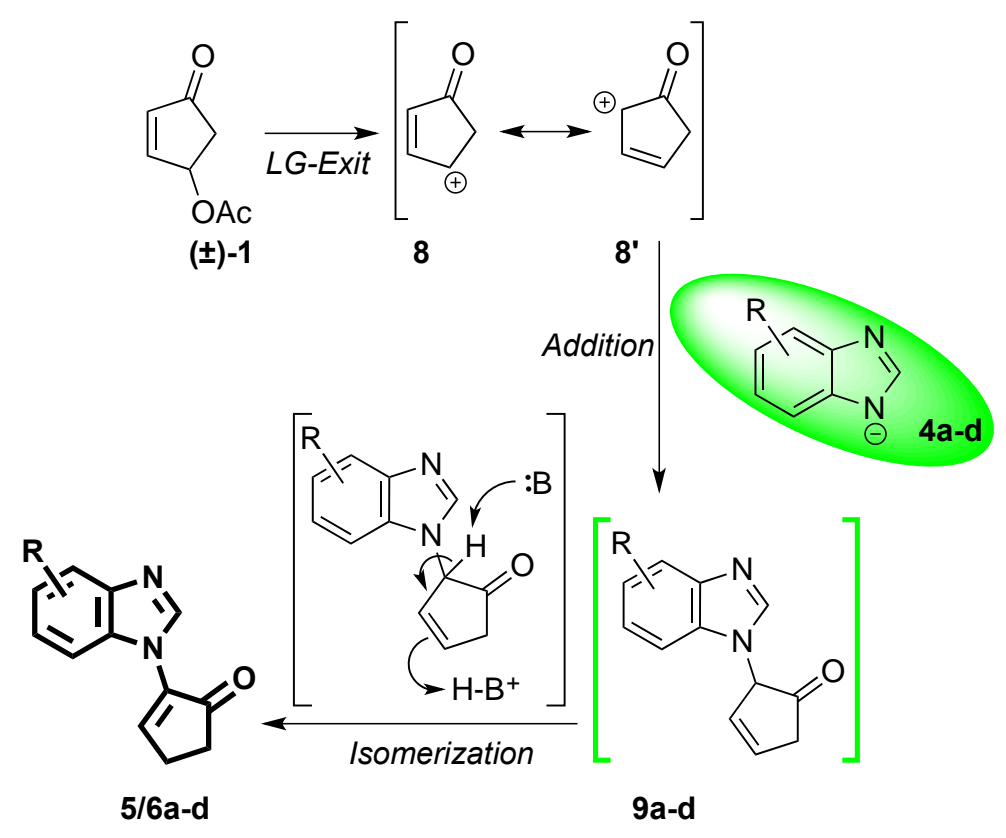

Scheme 3. Synthesis of 2-benzoimidazole-cyclopentenone derivatives 5 and 6: mechanism.

The attributions given in Table 2 were corroborated through COSY and NOESY experiments performed on the methoxy derivatives $5 / 6 c$ that showed more separated signals with respect to the other compounds and similar intensities, thus allowing to perform efficiently these double resonance experiments. In particular in the NOESY experiment, the proton $\mathrm{H}_{\mathrm{C}^{\prime}}$ of $6 \mathrm{c}$ at $7.34 \delta$ gives a NOE spot with the methoxy group at $3.89 \delta$ as well as with the olefinic proton at $6.67 \delta$; this latter gives also a NOE spot with the $\mathrm{CH}=\mathrm{N}$ proton at $8.67 \delta$. On 
the other hand, in the case of compound 5c, the doublet at $7.90 \delta$ gives a single NOE spot with the olefinic proton at $6.59 \delta$; this latter also spatially interacts with the $\mathrm{CH}=\mathrm{N}$ proton at $8.76 \delta$. On the basis of these observations all the correlations for the structure assignments for the other compounds derive consequently. From the mechanistic point of view the structures of compounds $\mathbf{5 a - d , ~ 6 a - d}$ and $\mathbf{7}$ rely on a leaving group (LG)elimination-addition-isomerization process that starts from the acetate $\mathbf{1}$ (Scheme 3 ), affording the allyl cation $\mathbf{8} \Leftrightarrow \mathbf{8}$ ' that, under the reported experimental conditions, adds the benzoimidazole anions $\mathbf{4 a - d}$ to give the notisolable adducts $\mathbf{9 a - d}$. These latters undergo $\mathrm{C}=\mathrm{C}$ double bond isomerization to the final products $\mathbf{5 / 6 a - d}$. The proposed mechanism has been previously demonstrated upon starting from enantiomerically enriched acetate 1 that could not afford any optically active products but just racemic compounds, as a definitive confirm that the allyl cation of type $\mathbf{8}$ is involved in the product formation and that a $S_{N} 2$ type nucleophilic substitution can be discarded among the possible reaction routes. ${ }^{8}$

Another key point about the synthetized compounds regards their thermal and photochemical stability. We have investigated this point taking into account previous observation ${ }^{8}$ and in view of novel opportunities for a further functionalization of the products at hand, useful for SAR studies that potentially require structural changes. Compounds 5/6a-d were heated at refluxing methanol for several hours and the stability of the compounds monitored by TLC. After 24h, compounds 5/6a-d were found unchanged and the structure resistance upon moderate heating was confirmed by ${ }^{1} \mathrm{H}$ NMR spectra that gave the same signals as the original samples. On the other hand, when heated in the presence of bases (e.g. triethylamine) compounds 5/6a-d undergo decomposition leaving a detectable and isolable benzoimidazole residues and loosing the cyclopentenone moiety, reasonably as cyclopentadieneone as leaving group, as previously suggested. ${ }^{8}$

We have submitted samples of the compounds 5/6a-d to exposure to UV light at 254, 310 and $400 \mathrm{~nm}$ for a couple of hours to test their photostability. Even in these cases we noted the release of the benzoimidazolic moieties that could be detected as the only structures reasonably attributable to the residues left after the photochemical processes, being the cyclopentenone moiety completely lost.

In summary, we can conclude that these structures are thermally (in the presence of bases) and photochemically labile and, unless with the help of further structural modifications able to stabilize them, hardly employed in experimental conditions that activate the loss of the cyclopentenone moiety.

For the antiviral evaluation, samples of the synthetized compounds compounds were sent to the NIAID (NIH, USA $)^{12}$ for in-vitro tests against a variety of viruses for a primary screening study. Products 5/6a-d were tested against the Herpesviridae family, Varicella-Zoster virus, (VZV), from the Hepatic virus HBV, Respiratory Viruses such as Influenza A virus H1N1 (IV/H1N1), Adenovirus-5 (AD5), from the Togavidae family, Chikungunya virus (CV), from the Flaviridae group, Yellow Fever Virus (YFV), from the Bunyaviridae family, Punta Toro Virus (PTV), and from the Papovaviridae the Human Papilloma Virus (HPV).

Compounds 5/6a-d were found inactive against VZV; although the $\mathrm{CC}_{50}$ is $>150$ (identical to Aciclovir used as reference compound), the $\mathrm{EC}_{50}$ was $>150$, enormously higher than the reference. Similarly, compounds 5/6a-d were found inactive against HBV; lamivudine (used as reference compound) has an $\mathrm{EC}_{50}=0.041$ compared with that of 5/6a-d $>100$. The primary antiviral data of compounds 5/6a-d against IV/H1N1 and AD5 were compared with the relative reference compounds and show that compounds $5 / 6 a, b, d$ were found inactive while $\mathbf{5 / 6 c}$ that bears a methoxy substituent showed a modest activity although the $\mathrm{EC}_{50}$ is more than 10 times that of Ribavirin. On the other hand, the activities against AD5 were disappointing. Table 3 gathers the $\mathrm{EC}_{50}, \mathrm{CC}_{50}$ and $\mathrm{SI}_{50}$ values $(\mu \mathrm{g} / \mathrm{mL})$ obtained in the in vitro tests against the reported viruses for the compound $\mathbf{5 / 6 c}$, only. A complete data table for all the compounds can be found in the SM.

Finally, the primary tests against YFV and CV demonstrated a total inefficacy of all the compounds against these viruses as well as of the tests against PTV and HPV. 
On the basis of these results we have focused our attention to the possible two conformers of the benzoimidazole-cyclopentenone structures and the methoxy derivatives for planning further derivatizations apt to strongly modify the structures at different positions of the entire skeleton, triggering a more effective biological activity. We have located the more stable optimized conformation of adduct 7 and those of the two methoxy derivatives $5 \mathrm{c}$ and $6 \mathrm{c}$ at the B3LYP(6-31G)(d) level. ${ }^{13}$

Table 3. Primary antiviral activities of compounds 5a-d and 6a-d against IV/H1N1

\begin{tabular}{|c|c|c|c|c|c|}
\hline Entry & Compound & $\begin{array}{l}\text { Drug Assay Name } \\
\text { (Cytopathic eff.) }\end{array}$ & $\mathrm{EC}_{50}$ & $\mathrm{CC}_{50}$ & $\mathrm{SI}_{50}$ \\
\hline & & $I V / H 1 N 1^{\mathrm{a}}$ & & & \\
\hline \multirow[t]{3}{*}{1} & $5 / 6 c$ & Visual & 15 & $>100$ & $>6.7$ \\
\hline & & Neutral Red & 25 & $>100$ & $>4.0$ \\
\hline & & $I V / H 1 N 1^{a}$ & & & \\
\hline \multirow[t]{2}{*}{2} & Ribavirin ${ }^{\mathrm{b}}$ & Visual & 1.2 & $>320$ & $>270$ \\
\hline & & Neutral Red & 1.4 & $>320$ & $>270$ \\
\hline
\end{tabular}

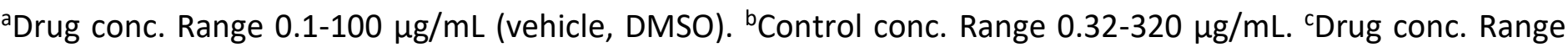
0.048-150 $\mu \mathrm{M}$ (vehicle, DMSO). ${ }^{\mathrm{d}}$ Control conc. Range 0.048-150 $\mu \mathrm{M}$.

Figure 1 shows the optimized structures with relative energies. The two types of conformers have been identified as sin and anti on the basis of the relative position of the cyclopentenone carbonyl group and the $\mathrm{H}$ $\mathrm{C}=\mathrm{N}$ proton of the imidazole ring. Conformer $7 \sin$ was found more stable than 7 anti by $1.91 \mathrm{kcal} / \mathrm{mol}$ and shows a stabilizing intramolecular $\mathrm{H}$-bonding between the $\mathrm{H}-\mathrm{C}=\mathrm{N}$ proton of the imidazole ring and the cyclopentenone carbonyl group at a distance of $2.34 \AA \AA$. The intramolecular $\mathrm{H}$-bonding keeps the benzoimidazole ring of the $7 \sin$ conformer slightly tilted by $26.4^{\circ}$ with respect to the cyclopentenone average plane. Conformer 7 anti does not gain any stabilizing effect through $\mathrm{H}$-bonding and the two rings are tilted by $44.4^{\circ}$.

Moving to the methoxy derivatives that showed the most promising antiviral activities against the IV/H1N1, the comparison of the conformers offer a similar picture. Conformer $\mathbf{5 c s i n}$ is more stable than $\mathbf{5 c a n t i}$ by $1.99 \mathrm{kcal} / \mathrm{mol}$ and stabilized by an intramolecular $\mathrm{H}$-bonding $(2.33 \AA$ ) with the two sings on different planes (dihedral angle $25.4^{\circ}$ ). Conformer $6 \mathrm{csin}$ is more stable than $6 \mathrm{canti}$ by $1.62 \mathrm{kcal} / \mathrm{mol}$ and stabilized by an intramolecular $\mathrm{H}$-bonding $\left(2.34 \AA\right.$ ) ) with the two sings on different planes (dihedral angle $36.1^{\circ}$ ). The absence of a stabilizing intramolecular $\mathrm{H}$-bonding in the comformers of type anti brings the two cyclic moieties of the molecules (cyclopentenone and methoxy-benzoimidazole) to be tilted by larger dihedral angles (up to $50^{\circ}$ ). 


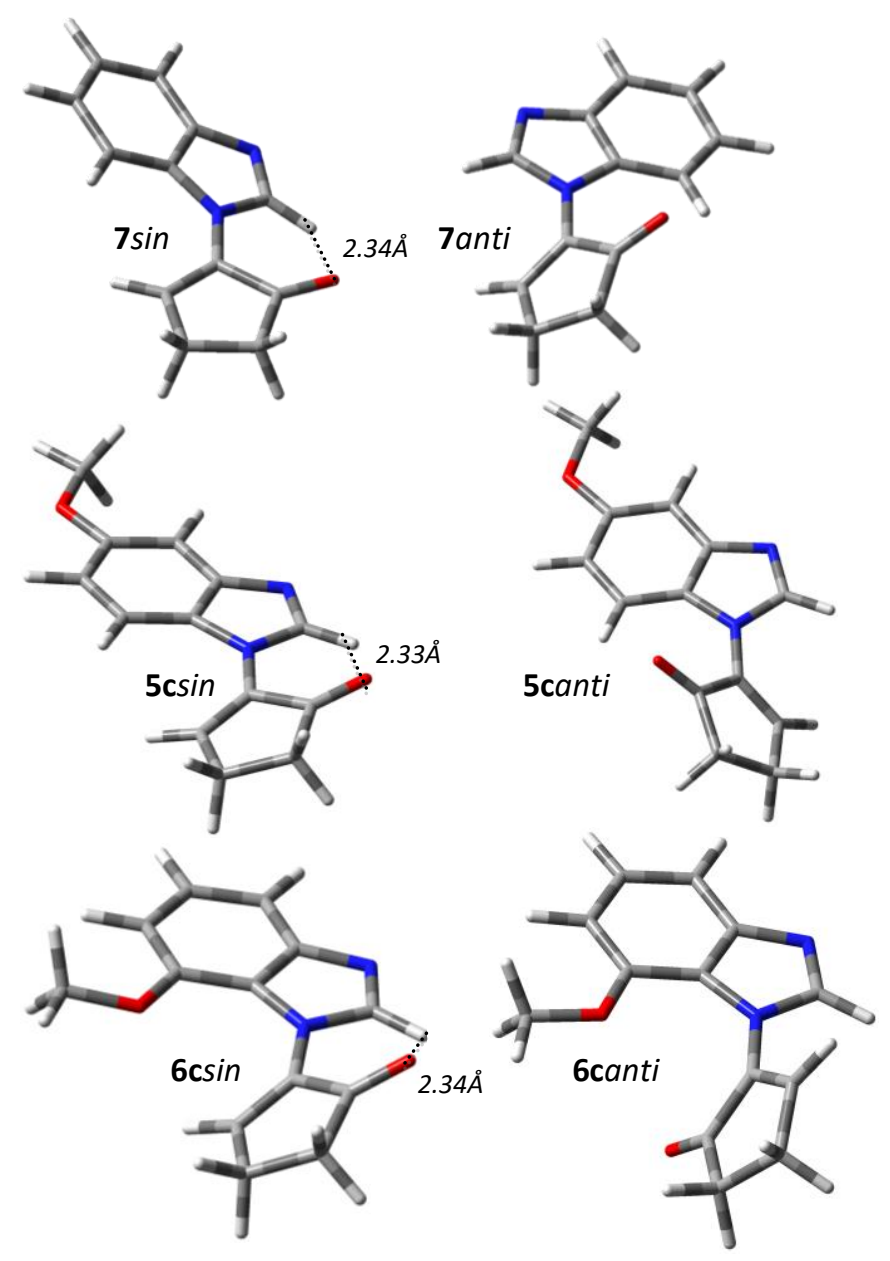

Figure 1. Optimized conformers of benzoimidazole-cyclopentenone $\mathbf{7}$ and methoxy derivatives $\mathbf{5 c}$ and $\mathbf{6 c}$. Values in $\AA$ indicate the $\mathrm{H}$-bonding distances.

These conformational pictures somewhat suggest scope and limitations in the modification and/or derivatization of compounds $\mathbf{5 / 6}$ and $\mathbf{7}$. Three main synthetic pathways can be considered to tune the biological activities and to solve the regioselectivity outcome relative to the heterocyclic moiety and are sketched in Scheme 4 . The $\mathrm{C}=\mathrm{C}$ double bond, the carbonyl group of the cyclopentenone moiety and the substituent on the benzoimidazole ring can be the three sites where synthetic modifications are possible. The most intriguing is represented by the functionalization of the $\mathrm{C}=\mathrm{C}$ double bond through 1,3-dipolar cycloaddition of stable nitrile oxides (Scheme 4, path a) and it also represents a challenging task since it would furnish a regioisomeric mixture of cycloadducts of type $\mathbf{8 A}, \mathbf{B}$ having the bicyclic structure of $6 \mathrm{a}-(1 \mathrm{H}$ benzo[d]imidazol-1-yl)-3a,4,5,6a-tetrahydro-6H-cyclopenta[d]isoxazol-6-ones, a class of heterocyclic substituted cyclopenta-isoxazolones often found in natural products and biologically active compounds. ${ }^{14}$ The potential obstacle in performing these reactions could be the steric availability of the $\mathrm{C}=\mathrm{C}$ double bond. In $\mathrm{H}$ bonded constrained structures, this could be detrimental for the cycloaddition reaction success, which is sterically demanding. On the other hand, the activation of the anti conformations by interrupting the intramolecular $\mathrm{H}$-bonds (solvent and temperature effects) could offer a solution to get the final goal. Moreover, these structures nicely resemble those of hexahydropentalen-1(2H)-one compounds that are useful scaffolds for the synthesis of sesquiterpenes. ${ }^{15,16}$ 


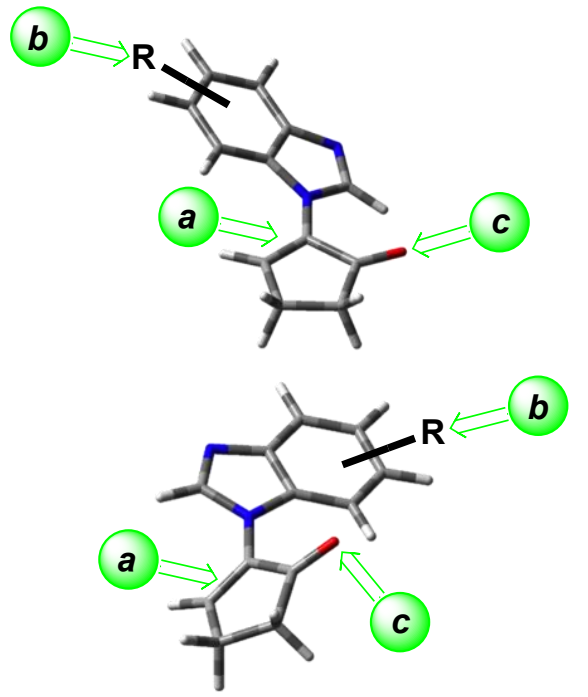

a) Double bond derivatization

b) Substituent modification

c) Carbonyl group derivatization
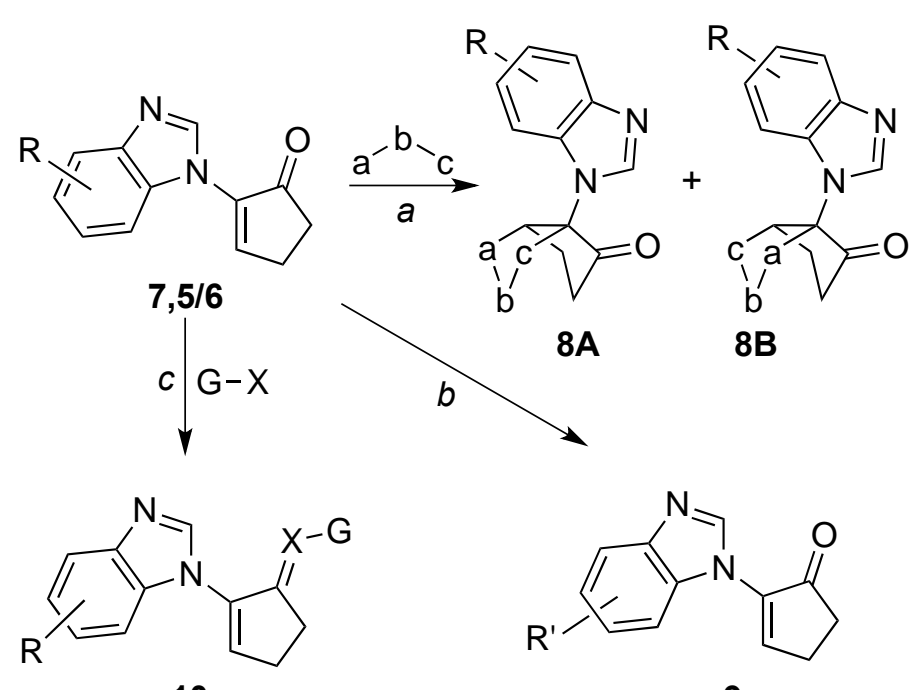

10

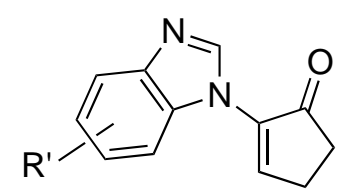

9

Scheme 4. Strategies for the synthetic elaboration of 2-benzoimidazole-cyclopentenone derivatives 5 and 6.

On the other side, a chemical modification of the substituent on the phenyl ring of the benzoimidazole moiety as well as the derivatization of the carbonyl group (Scheme 4, paths $b$ and c) will determine potential key point to tune properly the biological performances of the designed compounds. ${ }^{17,18}$ If the changes accordingly path $b$ seem to be highly risky and affect directly the reactivity of the benzene ring, the functionalization of the carbonyl group (path c) again calls into question the role of the intramolecular $\mathrm{H}$ bonding to let the carbonyl group free for nucleophilic addition reactions, as an example.

Before starting to investigate in full these opportunities, preliminary results indicate that the reaction between the benzoimidazole derivative $\mathbf{7}$ and mesitonitrile oxide can afford the expected regioisomeric cycloadduct of type $\mathbf{8}$ (Scheme 4, a-b-c = Mes-C=N-O). Being mesitonitrile oxide a typical stable nitrile oxide that operates in the absence of any kind of base (detrimental for the dipolarophile) it will be one of the 1,3-dipole of choice for conducting these studies for the synthesis of cyclopenta[ $d]$ isoxazol-6-one structures, to be evaluated for their potential biological activities. ${ }^{19-21}$ As a final remark, these structural changes and derivatizations will definitively help in the separation of the regioisomeric compounds of type $\mathbf{5}$ and $\mathbf{6}$, whose biological evaluation will be now possible on single regioisomeric structures.

\section{Conclusions}

In conclusion, we have reported a selective approach to 2-heterosubstituted cyclopent-2-en-1-ones through a valuable protocol that avoids the presence of side regiosiomeric compounds. The methodology has been applied to substituted benzoimidazole as model heterocyclic systems in view of future introduction of other compounds as well as suitable for further transformations as function of the tested biological activity as antivirals. By virtue of NMR investigations the synthetized compounds were structurally completely defined and the conformations were also located from theoretical investigation with DFT calculations. The preliminary biological in vitro tests revealed a general inactivity for most of the products with significant indication for 
some of them bearing specific substituents. These results immediately suggested possible structural changes apt to trigger the relative biological activities.

\section{Experimental Section}

General. All melting points are uncorrected. Elemental analyses were done on a C. Erba 1106 elemental analyzer. IR spectra (Nujol mulls for solids) were recorded on an FT-IR Perkin-Elmer RX-1. ${ }^{1} \mathrm{H}-$ and ${ }^{13} \mathrm{C}-\mathrm{NMR}$ spectra were recorded on a Bruker AVANCE 400 and 300 in the specified deuterated solvents. Chemical shifts are expressed in ppm from internal tetramethylsilane $(\delta)$. Column chromatography and tlc: silica gel 60 (0.063$0.200 \mathrm{~mm}$ ) (Merck); eluent cyclohexane/ethyl acetate from 9:1 to 5:5. MPLC chromatographic separations were performed on a Biotage Flash Master Personal apparatus; eluent cyclohexane/ethyl acetate from 9:1 to 5:5. Furfuryl alcohol, benzoimidazole and substituted benzoimidazoles were purchased from Sigma-Aldrich. All other reagents and solvents were purchased from Sigma-Aldrich and Alfa-Aesar and used without any further purification.

Synthesis of 2-(5-substituted-1H-benzo[d]imidazol-1-yl)cyclopent-2-en-1-ones (5a-d) and 2-(6-substituted1H-benzo[d]imidazol-1-yl)cyclopent-2-en-1-ones (6a-d); (general procedure). An excess of 5-substituted benzoimidazoles 4a-d (1.5 equiv.) were dissolved in $8 \mathrm{~mL}$ of anhydrous acetonitrile and 1.7 equiv. $\mathrm{NaH} 95 \%$ were added portionwise under stirring in a Schlenk tube at room temperature, applying mechanical vacuum until complete evolution of hydrogen gas. After 15 minutes, $1 \mathrm{~g}$ (7.14 mmol) of the 4-hydroxy-2cyclopentenone acetate ( $\mathbf{\pm})-\mathbf{1}$ was dissolved in the minimum amount of anhydrous acetonitrile and added to the solution under stirring. The reactions are left under stirring at room temperature overnight. The reactions were quenched with ice mixed with $\mathrm{NaCl} / \mathrm{NH}_{4} \mathrm{Cl}$ 1:3 and the water phase extracted with DCM. The organic phases were dried over $\mathrm{Na}_{2} \mathrm{SO}_{4}$ and, upon evaporation of the solvent, the residues were submitted to chromatographic separation to isolate the purified products $\mathbf{5 / 6 a - d . ~}$

5/6a (0.8 g, 53\%) as a straw yellow solid; [Found: $\mathrm{C}, 73.6 ; \mathrm{H}, 5.7 ; \mathrm{N}, 13.2 \% . \mathrm{C}_{13} \mathrm{H}_{12} \mathrm{~N}_{2} \mathrm{O}$ requires $\mathrm{C}, 73.56 ; \mathrm{H}$, 5.70; N, 13.20\%]; $R_{f}(100 \% \mathrm{MeOH}) 0.59 ; v_{\max }$ (nujol) 1686, $1607 \mathrm{~cm}^{-1} ; \delta_{\mathrm{H}}(300 \mathrm{MHz} \mathrm{DMSO}) 2.46\left(3 \mathrm{H}, \mathrm{s}, \mathrm{C}_{3}\right)$, $2.50\left(3 \mathrm{H}, \mathrm{s}, \mathrm{C}_{3}\right), 2.54\left(2 \mathrm{H}, \mathrm{m}, \underline{\mathrm{C}}_{2}\right), 3.37\left(2 \mathrm{H}, \mathrm{m}, \mathrm{C}_{2}\right), 6.64(1 \mathrm{H}, \mathrm{s}, \mathrm{C} \underline{\mathrm{H}}=), 6.67(1 \mathrm{H}, \mathrm{s}, \mathrm{C} \underline{\mathrm{H}}=), 7.24(1 \mathrm{H}+1 \mathrm{H}, \mathrm{t}, \mathrm{J} 7$ $\mathrm{Hz}$, arom.), $7.60(1 \mathrm{H}, \mathrm{s}$, arom.), $7.66(1 \mathrm{H}, \mathrm{d}, J 9 \mathrm{~Hz}$, arom.), $7.81(1 \mathrm{H}, \mathrm{s}, \mathrm{arom}),. 7.86(1 \mathrm{H}, \mathrm{d}, J 9.0 \mathrm{~Hz}$, arom.), 8.69 $(1 \mathrm{H}, \mathrm{s}, \mathrm{C} \underline{\mathrm{H}}=\mathrm{N}), 8.72(1 \mathrm{H}, \mathrm{s}, \mathrm{C} \underline{\mathrm{H}}=\mathrm{N}) ; \delta_{\mathrm{c}}(75.0 \mathrm{MHz}, \mathrm{DMSO}) 205.8,205.7,165.6,165.5,144.9,142.7,142.6,142.2$, 134.8, 133.6, 132.0, 129.8, 126.1, 125.5, 120.2, 119.9, 113.7, 113.6, 113.5, 113.2, 33.4, 28.1, 28.0, 21.3, 20.9.

5/6b $(1.0 \mathrm{~g}, 60 \%)$ as a straw yellow solid; [Found: $\mathrm{C}, 62.0 ; \mathrm{H}, 3.9 ; \mathrm{N}, 12.0 \% . \mathrm{C}_{12} \mathrm{H}_{9} \mathrm{~N}_{2} \mathrm{OCl}$ requires $\mathrm{C}, 61.95 ; \mathrm{H}$, 3.90; $\mathrm{N}, 12.04 \%] ; \mathrm{R}_{\mathrm{f}}(100 \% \mathrm{MeOH}) 0.61 ; v_{\max }$ (nujol) 1674, $1618 \mathrm{~cm}^{-1} ; \delta_{\mathrm{H}}(300 \mathrm{MHz} \mathrm{DMSO}) 2.55\left(2 \mathrm{H}, \mathrm{m}, \mathrm{C}_{2}\right.$ ), $3.34\left(2 \mathrm{H}, \mathrm{m}, \underline{\mathrm{C}}_{2}\right), 6.67(1 \mathrm{H}, \mathrm{s}, \mathrm{C} \underline{\mathrm{H}}=), 6.75(1 \mathrm{H}, \mathrm{s}, \underline{\mathrm{CH}}=), 7.45(1 \mathrm{H}+1 \mathrm{H}, \mathrm{d}, \mathrm{J} 7 \mathrm{~Hz}$, arom.) $7.82(1 \mathrm{H}, \mathrm{d}, J 9 \mathrm{~Hz}, \mathrm{arom}$.$) ,$ $7.91\left(1 \mathrm{H}, \mathrm{s}\right.$, arom.), $8.11(1 \mathrm{H}, \mathrm{s}, \operatorname{arom}),. 8.87(1 \mathrm{H}, \mathrm{s}, \underline{\mathrm{CH}}=\mathrm{N}), 8.90(1 \mathrm{H}, \mathrm{s}, \mathrm{C} \underline{\mathrm{H}}=\mathrm{N}) ; \delta_{\mathrm{c}}(75.0 \mathrm{MHz}, \mathrm{DMSO}) 205.3$, 164.7, 143.4, 142.9, 132.0, 129.1, 124.4, 124.1, 121.2, 119.6, 114.6, 114.4, 114.1, 113.2, 33.1, 27.6.

5/6c (0.8 g, 51\%) as a light brown solid; [Found: $\mathrm{C}, 68.4 ; \mathrm{H}, 5.3 ; \mathrm{N}, 12.3 \% . \mathrm{C}_{13} \mathrm{H}_{12} \mathrm{~N}_{2} \mathrm{O}_{2}$ requires $\mathrm{C}, 68.41 ; \mathrm{H}, 5.30$; $\mathrm{N}, 12.27 \%] ; \mathrm{R}_{\mathrm{f}}(100 \% \mathrm{MeOH}) 0.60 ; \mathrm{v}_{\max }$ (nujol) 1684, $1607 \mathrm{~cm}^{-1} ; \delta_{\mathrm{H}}(300 \mathrm{MHz} \mathrm{DMSO}) 2.53\left(2 \mathrm{H}, \mathrm{m}, \mathrm{CH}_{2}\right), 3.36$ $\left(2 \mathrm{H}, \mathrm{m}, \mathrm{CH}_{2}\right), 3.84\left(3 \mathrm{H}, \mathrm{s}, \mathrm{CH}_{3} \mathrm{O}\right), 3.89\left(3 \mathrm{H}, \mathrm{s}, \mathrm{CH}_{3} \mathrm{O}\right), 6.59(1 \mathrm{H}, \mathrm{s}, \mathrm{C} \underline{\mathrm{H}}=), 6.67(1 \mathrm{H}, \mathrm{s}, \mathrm{C} \underline{\mathrm{H}}=), 7.00(1 \mathrm{H}, \mathrm{d}, J 2 \mathrm{~Hz}$, arom.), $7.02(1 \mathrm{H}, \mathrm{d}, J 2 \mathrm{~Hz}$, arom.), $7.34(1 \mathrm{H}, \mathrm{d}, J 2 \mathrm{~Hz}, \operatorname{arom}),. 7.36(1 \mathrm{H}, \mathrm{d}, J 2 \mathrm{~Hz}, \operatorname{arom}),. 7.68(1 \mathrm{H}, \mathrm{d}, J 8 \mathrm{~Hz}$, arom.), $7.90\left(1 \mathrm{H}, \mathrm{d}, J 8 \mathrm{~Hz}\right.$, arom.), $8.67(1 \mathrm{H}, \mathrm{s}, \mathrm{C} \underline{\mathrm{H}}=\mathrm{N}), 8.76(1 \mathrm{H}, \mathrm{s}, \mathrm{C} \underline{\mathrm{H}}=\mathrm{N}) ; \delta_{\mathrm{c}}(75.0 \mathrm{MHz}, \mathrm{DMSO}) 205.4,205.3$, 165.1, 165.0, 157.2, 156.4, 145.4, 142.8, 141.3, 138.3, 132.1, 125.6, 120.4, 113.6, 113.5, 113.1, 112.9, 112.5, $103.0,987.2,55.5,55.2,33.0,27.7,27.5$. 
5/6d (1.2 g, 67\%) as a brown solid; [Found: $\mathrm{C}, 59.3 ; \mathrm{H}, 3.7 ; \mathrm{N}, 17.3 \%$. $\mathrm{C}_{12} \mathrm{H}_{9} \mathrm{~N}_{3} \mathrm{O}_{3}$ requires $\mathrm{C}, 59.26 ; \mathrm{H}, 3.73 ; \mathrm{N}$, 17.28\%]; $R_{f}(100 \% \mathrm{MeOH}) 0.58 ; v_{\max }$ (nujol) 1692, $1590 \mathrm{~cm}^{-1} ; \delta_{\mathrm{H}}(300 \mathrm{MHz} \mathrm{DMSO}) 2.58\left(2 \mathrm{H}, \mathrm{m}, \mathrm{C}_{2}\right), 3.42(2 \mathrm{H}$, m, $\left.\underline{C H}_{2}\right), 6.78(1 \mathrm{H}, \mathrm{s}, \underline{\mathrm{C}} \underline{\mathrm{H}}=), 6.80(1 \mathrm{H}, \mathrm{s}, \underline{\mathrm{C}} \underline{\mathrm{H}}=), 8.02(1 \mathrm{H}, \mathrm{d}, J 9 \mathrm{~Hz}$, arom.), 8.27 (3H, s, arom.), 8.65 (1H, bs, arom.), $8.71\left(1 \mathrm{H}, \mathrm{d}, J 2 \mathrm{~Hz}\right.$, arom.), $9.10(1 \mathrm{H}, \mathrm{s}, \mathrm{C} \underline{\mathrm{H}}=\mathrm{N}), 9.17(1 \mathrm{H}, \mathrm{s}, \mathrm{C} \underline{\mathrm{H}}=\mathrm{N}) ; \delta_{c}(75.0 \mathrm{MHz}, \mathrm{DMSO}) 205.7,205.6$, $165.0,164.9,148.8,147.7,146.4,144.5,144.2,144.1,135.9,131.2,120.9,119.9,119.6,116.1,116.06,115.8$, $114.3,109.9,33.7,33.6,28.1,28.05$.

Synthesis of 2-(1H-benzo[d]imidazol-1-yl)cyclopent-2-en-1-one (7). An excess of benzoimidazole (1.5 equiv.) was dissolved in $8 \mathrm{~mL}$ of anhydrous acetonitrile and 1.7 equiv. $\mathrm{NaH} \mathrm{95 \%} \mathrm{were} \mathrm{added} \mathrm{portionwise} \mathrm{under} \mathrm{stirring}$ in a Schlenk tube, applying mechanical vacuum until complete evolution of hydrogen gas. After 15 minutes, 1 $\mathrm{g}(7.14 \mathrm{mmol})$ of the 4-hydroxy-2-cyclopentenone acetate $(\mathbf{\pm})-\mathbf{1}$ was dissolved in the minimum amount of anhydrous acetonitrile and added to the solution under stirring. The reaction is left under stirring at room temperature overnight. The reaction was quenched with ice mixed with $\mathrm{NaCl} / \mathrm{NH}_{4} \mathrm{Cl} 1: 3$ and the water phase extracted with DCM. The organic phases were dried over $\mathrm{Na}_{2} \mathrm{SO}_{4}$ and, upon evaporation of the solvent, the residue was submitted to chromatographic separation to isolate the purified product 7.

$7(1.0 \mathrm{~g}, 70 \%)$ as a light brown solid; [Found: $\mathrm{C}, 72.7 ; \mathrm{H}, 5.1 ; \mathrm{N}, 14.1 \% . \mathrm{C}_{12} \mathrm{H}_{10} \mathrm{~N}_{2} \mathrm{O}$ requires $\mathrm{C}, 72.71 ; \mathrm{H}, 5.09 ; \mathrm{N}$, 14.13\%]; $R_{f}(100 \% \mathrm{MeOH}) 0.62 ; v_{\max }$ (nujol) 1678, 1581 $\mathrm{cm}^{-1} ; \delta_{\mathrm{H}}(300 \mathrm{MHz} \mathrm{DMSO}) 2.55\left(2 \mathrm{H}, \mathrm{m}, \mathrm{CH}_{2}\right), 3.39(2 \mathrm{H}$, $\left.\mathrm{m}, \mathrm{C}_{2}\right), 6.65(1 \mathrm{H}, \mathrm{s}, \underline{\mathrm{CH}}=), 7.43(1 \mathrm{H}+1 \mathrm{H}, \mathrm{m}, \operatorname{arom}),. 7.81(1 \mathrm{H}, \mathrm{m}$, arom.), $8.03(1 \mathrm{H}, \mathrm{m}$, arom. $), 8.83(1 \mathrm{H}, \mathrm{s}$, $\mathrm{C} \underline{\mathrm{H}}=\mathrm{N}) ; \delta_{\mathrm{C}}(75.0 \mathrm{MHz}, \mathrm{DMSO}) 205.3,165.2,144.2,142.4,131.4,124.5,123.8,120.0,113.5,113.3,33.0,27.7$.

\section{Biological tests}

Antiviral assays. The National Institute of Allergy and Infectious Diseases (NIAID) provides free and confidential services for suppliers, who are interested in submitting compounds to be evaluated for antiviral activity. Tested compounds were delivered in standard DMSO solutions. The methods applied for the different assays can be found at the URL via the internet at http://niaid-aacf.org.

Compounds 5/6a-d were tested against the Herpesviridae family, Varicella-Zoster virus, (VZV, virus strain, Ellen, cell line, HFF), from the Hepatic virus HBV (virus strain ayw; cell line 2.2.15), Respiratory Viruses such as Influenza A virus H1N1 (IV/H1N1, virus strain, InfluenzaA/California/7/2009; cell line, MDCK), Adenovirus-5 (AD5, Adenoid75, virus strain; cell line, HFF), from the Togavidae family, Chikungunya virus (CV, virus strain, S27/VR-64, cell line, Vero 76), from the Flaviridae group, Yellow Fever Virus (YFV, virus strain, 17D; cell line, Huh7), from the Bunyaviridae family, Punta Toro Virus (PTV, virus strain, Adames; cell line, Vero 76), and from the Papovaviridae the Human Papilloma Virus (HPV, virus strain, HE611260.1; cell line, C-33A).

\section{Acknowledgements}

Financial support by University of Pavia and MIUR PRIN 2017, CUP: ) is gratefully acknowledged. The authors warmly thank the Salahaddin University of Erbil (Iraq) for valuable support and grant (KKH). Thanks are also due to "VIPCAT - Value Added Innovative Protocols for Catalytic Transformations" project (CUP: E46D17000110009) for valuable financial support.

Thanks are due to Dr. D. Smee (Utah State University) for PT, YFV, CV and H1N1 virus tests, to Dr. B. Korba (Georgetown University Med. Center) for HBV tests and to Dr. M. Prichard (University of Alabama at Birmingham) for VZV, HPV and AD-5 virus tests. 


\section{Supplementary Material}

${ }^{1} \mathrm{H},{ }^{13} \mathrm{C}$, COSY and NOESY spectra, Cartesian coordinates of calculated structures are given in the supplementary material file associated to this manuscript.

\section{References}

1. Roche, S. P.; Aitken, D. J. Eur. J. Org. Chem. 2010, 5339-5358. https://doi.org/10.1002/ejoc.201000704

2. Aitken, D. J.; Eijsberg, H.; Frongia, A.; Ollivier, J.; Piras, P. P. Synthesis 2014, 46, 1-24. https://doi.org/10.1055/s-0033-1340414

3. Weising, S.; Dekiert, P.; Schols, D.; Neyts, J.; Meier, C. Synthesis, 2018, 50, 2266-2280. https://doi.org/10.1055/s-0037-1609493

4. Ruider, S. A.; Carreira, E. M. Org. Lett. 2016, 18, 220-223. https://doi.org/10.1021/acs.orglett.5b03356

5. Ulbrich, K.; Kreitmeier, P.; Vilaivan, T.; Reiser, O. J. Org. Chem. 2013, 78, 4202-4206. https://doi.org/10.1021/j0400409f

6. Arisetti, N.; Reiser, O. Org. Lett. 2015, 17, 94-97. https://doi.org/10.1021/ol5032975

7. Dobler, D.; Reiser, O. J. Org. Chem. 2016, 81, 10357-10365. https://doi.org/10.1021/acs.joc.6b01339

8. Mantione, D.; Olaizola Aizpuru, O.; Memeo, M. G.; Bovio, B.; Quadrelli, P. Eur. J. Org. Chem. 2016, $983-991$. https://doi.org/10.1002/ejoc.201501406

9. Khanapure, S. P.; Najafi, N.; Manna, S.; Yang, J.-J.; Rokach, J. J. Org. Chem. 1995, 60, 7548-7551. https://doi.org/10.1021/jo00128a029

10. Curran, T. T.; Hay, D. A.; Koegel, C. P. Tetrahedron 1997, 53, 1983-2004. https://doi.org/10.1016/S0040-4020(96)01169-6https://doi.org/10.1002/ejoc.201000704

11. Roche, S. P.; Aitken, D. J. Eur. J. Org. Chem. 2010, 5339-5358. https://doi.org/10.1002/ejoc.201000704

12. For further information see the URL via the internet at http://niaid-aacf.org.

13. Gaussian 09, Revision E.01, Frisch, M. J.; Trucks, G. W.; Schlegel, H. B.; Scuseria, G. E.; Robb, M. A.; Cheeseman, J. R.; Scalmani, G.; Barone, V.; Mennucci, B.; Petersson, G. A.; Nakatsuji, H.; Caricato, M.; Li, X.; Hratchian, H. P.; Izmaylov, A. F.; Bloino, J.; Zheng, G.; Sonnenberg, J. L.; Hada, M.; Ehara, M.; Toyota, K.; Fukuda, R.; Hasegawa, J.; Ishida, M.; Nakajima, T.; Honda, Y.; Kitao, O.; Nakai, H.; Vreven, T.; Montgomery, J. A., Jr.; Peralta, J. E.; Ogliaro, F.; Bearpark, M.; Heyd, J. J.; Brothers, E.; Kudin, K. N.; Staroverov, V. N.; Kobayashi, R.; Normand, J.; Raghavachari, K.; Rendell, A.; Burant, J. C.; Iyengar, S. S.; Tomasi, J.; Cossi, M.; Rega, N.; Millam, J. M.; Klene, M.; Knox, J. E.; Cross, J. B.; Bakken, V.; Adamo, C.; Jaramillo, J.; Gomperts, R.; Stratmann, R. E.; Yazyev, O.; Austin, A. J.; Cammi, R.; Pomelli, C.; Ochterski, J. W.; Martin, R. L.; Morokuma, K.; Zakrzewski, V. G.; Voth, G. A.; Salvador, P.; Dannenberg, J. J.; Dapprich, S.; Daniels, A. D.; Farkas, Ö.; Foresman, J. B.; Ortiz, J. V.; Cioslowski, J.; Fox, D. J. Gaussian, Inc., Wallingford CT, 2009.

14. Garcia Ruano, J. L.; Soriano, J. F.; Fraile, A. ; Rosario Martin, M.; Nunez, A. J. Sulfur Chem. 2013, 34, 17-32. https://doi.org/10.1080/17415993.2012.705286

15. Schmidt, A. W.; Olpp, T.; Schmid, S.; Goutal, S.; Jäger, A.; Knölker, H.-J. Synlett 2007, 1549-1552. 
16. Kraus, G. A.; Shi, J. J. Org. Chem. 1990, 55, 5423-5424.

https://doi.org/10.1021/jo00307a001

17. Rieder, C. J.; Fradette, R. J.; West, F. G. Chem. Commun. 2008, 1572-1574.

18. Rieder, C. J.; Fradette, R. J.; West, F. G. Heterocycles 2010, 80, 1413-1427. https://doi.org/10.3987/COM-09-S(S)132

19. Garrouch, I.; Mehdi. Rammah, M.; Askri, M.; Baker Rammah, M.; Knorr, M.; Strohmann, C. J. Soc. Chim. Tun. 2009, 11, 21-27.

20. Quadrelli, P.; Fassardi, V.; Cardarelli, A.; Caramella, P. Eur. J. Org. Chem. 2002, 2058-2065. https://doi.org/10.1002/1099-0690(200207)2002:13<2058::AID-EJOC2058>3.0.CO;2-Z

21. Fassardi, V.; Basile, T.; Memeo, M. G.; Quadrelli, P. Tetrahedron Lett. 2017, 58, 3385-3389. https://doi.org/10.1016/j.tetlet.2017.07.056 